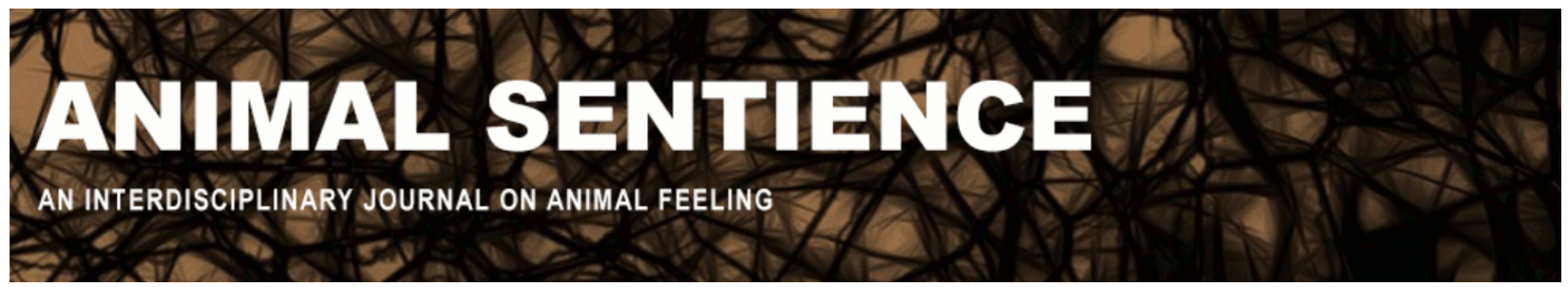

Diggles, Ben and Browman, Howard I. (2018) Denialism and muddying the water or organized skepticism and clarity? THAT is the question. Animal Sentience 21(10)

DOI: $10.51291 / 2377-7478.1349$

Date of submission: 2018-06-15

Date of acceptance: 2018-06-19

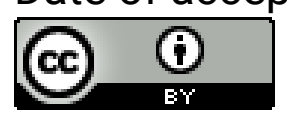

This article has appeared in the journal Animal

Sentience, a peer-reviewed journal on animal

cognition and feeling. It has been made open access,

free for all, by WellBeing International and deposited

in the WBI Studies Repository. For more information,

please contact

wbisr-info@wellbeingintl.org.

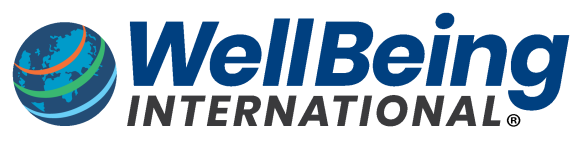

SOLUTIONS FOR PEOPLE, ANIMALS AND ENVIRONMENT 


\title{
Denialism and muddying the water or organized skepticism and clarity? THAT is the question
}

Commentary on Sneddon et al. on Sentience Denial

\author{
Ben Diggles ${ }^{1} \&$ Howard I. Browman ${ }^{2}$ \\ ${ }^{1}$ DigsFish Services Pty Ltd, Banksia Beach, QLD, Australia \\ ${ }^{2}$ Institute of Marine Research, Austevoll Research Station, Storeb $\varnothing$, Norway
}

\begin{abstract}
The research being commented on here has been criticized and defended in journals. Sneddon et al. (2018) add nothing substantive. We have nothing further to add. Readers are referred to Diggles (2018) and to Browman et al. (2018) for a detailed assessment.
\end{abstract}

Keywords: anthropomorphism, crustacea, fish, misrepresentation, nociception, pain, skepticism

Ben Diggles is an aquatic animal health specialist who for the last 25 years has studied various aspects relating to health, welfare and diseases of wild and captive fish, crustaceans and molluscs in both fisheries and aquaculture. Website

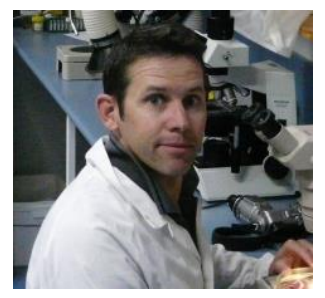

Howard I. Browman is principal research scientist at Institute of Marine Research, Norway, a government research institute that generates science and provides advice on the sustainable use of marine resources. He is also Editor-in-Chief of Journal of Marine Science, owned by the International Council for the Exploration of the Sea (ICES), a global intergovernmental organization that develops science and provides advice

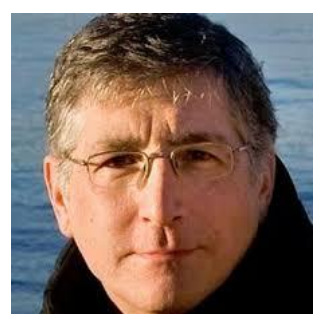
to support the sustainable use of the oceans. Website

\footnotetext{
"The improver of natural knowledge absolutely refuses to acknowledge authority, as such. For him, scepticism is the highest of duties; blind faith the one unpardonable sin." (T.H. Huxley 1866)
}

High scientific standards dictate that research is properly designed, implemented without artefact, interpreted conservatively without spin (Boutron and Ravaud 2018) and replicable by others. To ensure that this is the case, all research must be able to withstand close scrutiny, in the form of organized skepticism (Huxley 1866; May 2011). Organized scepticism is a norm of science and should not be misconstrued or misrepresented as anything other than an integral aspect of the scientific method. 
The body of research that Sneddon et al. (2018) defend has been subjected to organized skepticism - and defended - in the journals in which the original articles were published. In our view, Sneddon et al. add nothing substantive to those earlier exchanges beyond framing our valid criticisms as denialism and obfuscation (Jacquet 2018). We therefore have nothing further to say about the specifics they raise. Rather, we refer readers to Diggles (2018) for a detailed assessment of the research available to inform aquatic crustacean welfare, and to Browman et al. (2018) for a general treatment of the broader issues surrounding aquatic animal welfare, including the need for organized skepticism.

\section{References}

Boutron, I., \& Ravaud, P. (2018). Misrepresentation and distortion of research in biomedical literature. PNAS, 115, 2613-2619.

Browman, H. I., Cooke, S. J., Cowx, I. G., Derbyshire, S. W. G., Kasumyan, A., Key, B., Rose, J. D., Schwab, A., Skiftesvik, A. B., Stevens, E. D., Watson, C. A., \& Arlinghaus, R. (2018). Welfare of aquatic animals: Where things are, where they are going, and what it means for research, aquaculture, recreational angling and commercial fishing. ICES Journal of Marine Science.

Diggles, B. K. (2018). Review of some scientific issues related to crustacean welfare. ICES Journal of Marine Science.

Huxley, T. H. (1866). On the advisableness of improving natural knowledge. Fortnightly Review, 3, 626-637.

Jacquet, J. (2018). Defining denial and sentient seafood. Animal Sentience 21(8).

May, R. M. (2011). Science as organized scepticism. Philosophical Transactions of The Royal Society, 369, 4685-4689.

Sneddon, L. U., Lopez-Luna, J., Wolfenden, D. C. C., Leach, M. C., Valentim, A. M., Steenbergen, P. J., Bardine, N., Currie, A. D., Broom, D. M., \& Brown, C. (2018). Fish sentience denial: Muddying the waters. Animal Sentience 21(1). 


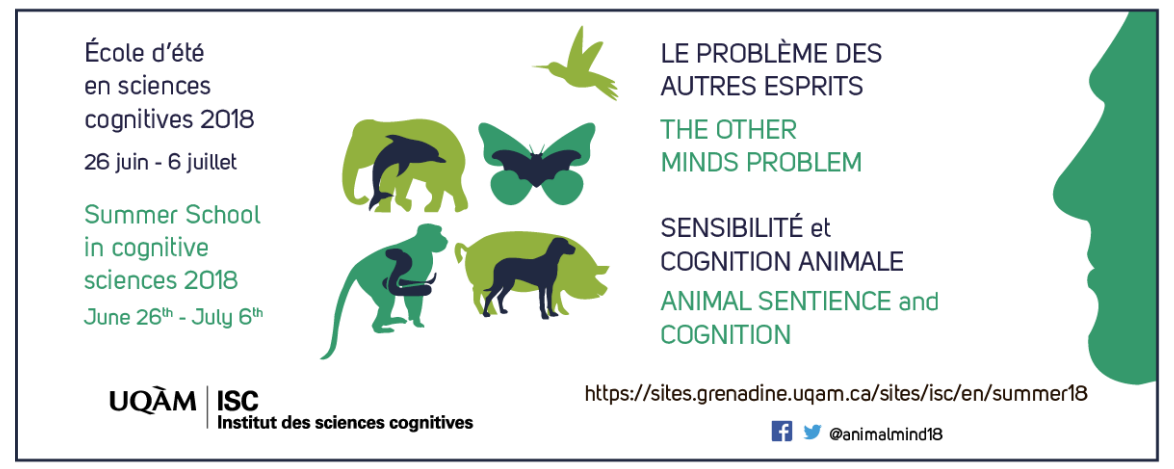

ISC 2018 Summer School in Cognitive Sciences June 26 - July 6, 2018 Montreal (Canada)

\section{The Other Minds Problem: Animal Sentience and Cognition}

Overview. Since Descartes, philosophers know there is no way to know for sure what — or whether — others feel (not even if they tell you). Science, however, is not about certainty but about probability and evidence. The 7.5 billion individual members of the human species can tell us what they are feeling. But there are 9 million other species on the planet (20 quintillion individuals), from elephants to jellyfish, with which humans share biological and cognitive ancestry, but not one other species can speak: Which of them can feel — and what do they feel? Their human spokespersons - the comparative psychologists, ethologists, evolutionists, and cognitive neurobiologists who are the world's leading experts in "mindreading" other species - will provide a sweeping panorama of what it feels like to be an elephant, ape, whale, cow, pig, dog, chicken, bat, fish, lizard, lobster, snail: This growing body of facts about nonhuman sentience has profound implications not only for our understanding of human cognition, but for our treatment of other sentient species.

|Gregory Berns: Decoding the Dog's Mind with Awake Neuroimaging

Gordon Burghardt: Probing the Umwelt of Reptiles

Jon Sakata: Audience Effects on Communication Signals

PANEL 1: Reptiles, Birds and Mammals

WORKSHOP 1: Kristin Andrews: The "Other" Problems: Mind,

Behavior, and Agency

Sarah Brosnan: $\underline{\text { How }}$ Do Primates Feel About Their Social Partners?

Alexander Ophir: The Cognitive Ecology of Monogamy

Michael Hendricks: Integrating Action and Perception in a Small

Nervous System

PANEL 2: Primates, Voles and Worms

WORKSHOP 2: Jonathan Birch: Animal Sentience and the

Precautionary Principle

Malcolm Maclver: How Sentience Changed After Fish Invaded Land

385 Million Years Ago

Sarah Woolley: Neural Mechanisms of Preference in Female

Songbird

Simon Reader: Animal Social Learning: Implications for

Understanding Others

PANEL 3: Sea to Land to Air

WORKSHOP 3: Steven M. Wise: Nonhuman Personhood

Tomoko Ohyama: Action Selection in a Small Brain (Drosophila

Maggot)

Mike Ryan: "Crazy Love": Nonlinearity and Irrationality in Mate Choice

Louis Lefebvre: Animal Innovation: From Ecology to

Neurotransmitters

PANEL 4: Maggots, Frogs and Birds: Flexibility Evolving

SPECIAL EVENT: Mario Cyr: Polar Bears

Colin Chapman: Why Do We Want to Think People Are Different?

Vladimir Pradosudov: Chickadee Spatial Cognition

Jonathan Balcombe: The Sentient World of Fishes

PANEL 5: Similarities and Differences

WORKSHOP 5 (part 1): Gary Comstock: A Cow's Concept of Her Future

WORKSHOP 5 (part 2): Jean-Jacques Kona-Boun: Physical and

Mental Risks to Cattle and Horses in Rodeos

\author{
Joshua Plotnik: Thoughtful Trunks: Application of Elephant Cognition \\ for Elephant Conservation \\ Lori Marino: Who Are Dolphins? \\ Larry Young: The Neurobiology of Social Bonding, Empathy and \\ Social Loss in Monogamous Voles \\ Panel 6: Mammals All, Great and Small \\ WORKSHOP 6: Lori Marino: The Inconvenient Truth About Thinking \\ Chickens \\ Andrew Adamatzky: Slime Mould: Cognition Through Computation \\ Frantisek Baluska \& Stefano Mancuso: What a Plant Knows and \\ Perceives \\ Arthur Reber: A Novel Theory of the Origin of Mind: Conversations \\ With a Caterpillar and a Bacterium \\ PANEL 7: Microbes, Molds and Plants \\ WORKSHOP 7: Suzanne Held \& Michael Mendl: Pig Cognition and \\ Why It Matters \\ James Simmons: What Is It Like To Be A Bat? \\ Debbie Kelly: Spatial Cognition in Food-Storing \\ Steve Phelps: Social Cognition Across Species \\ PANEL 8: Social Space \\ WORKSHOP 8: To be announced \\ Lars Chittka: The Mind of the Bee \\ Reuven Dukas: Insect Emotions: Mechanisms and Evolutionary \\ Biology \\ Adam Shriver: Do Human Lesion Studies Tell Us the Cortex is \\ Required for Pain Experiences? \\ PANEL 9: The Invertebrate Mind \\ WORKSHOP 9: Delcianna Winders: Nonhuman Animals in Sport \\ and Entertainment \\ Carel ten Cate: Avian Capacity for Categorization and Abstraction \\ Jennifer Mather: Do Squid Have a Sense of Self? \\ Steve Chang: Neurobiology of Monkeys Thinking About Other \\ Monkeys \\ PANEL 10: Others in Mind \\ WORKSHOP 10: The Legal Status of Sentient Nonhuman Species
}

